\title{
IMAGE
}

\section{Insights Image for "Rate of rise of total serum bilirubin in very low birth weight preterm infants"}

Sigrid Hahn ${ }^{1}$, Christoph Bührer ${ }^{1}$, Gerd Schmalisch ${ }^{1}$, Boris Metze ${ }^{1}$ and Monika Berns ${ }^{1}$

Pediatric Research (2020) 87:1135; https://doi.org/10.1038/s41390-019-0674-3

Hypothesized causal relation between the postnatal rate of rise of total serum bilirubin, associated risk factors, as well as timing and duration of phototherapy in very low birth weight preterm infants. ${ }^{1}$ a) Aspects of bilirubin metabolism in physically immature infants. ${ }^{2}$ BW, birth weight; GA, gestational age; RBC, red blood cell; $\mathrm{R}_{S}$, Spearman's rank coefficient; TSB, total serum bilirubin; TSB $\mathrm{ROR}$, rate of rise of total serum bilirubin $(\mathrm{mg} / \mathrm{dL} / \mathrm{h})$.

\section{REFERENCES}

1. Hahn, S. et al. Rate of rise of total serum bilirubin in very low birth weight preterm infants. Pediatr. res. (2019). https://doi.org/10.1038/s41390-019-0415-7. [Epub ahead of print].

2. Watchko, J. F. \& Maisels, M.J. Jaundice in low birthweight infants: pathobiology and outcome. Arch Dis Child Fetal Neonatal Ed. 88, F455-458 (2003).

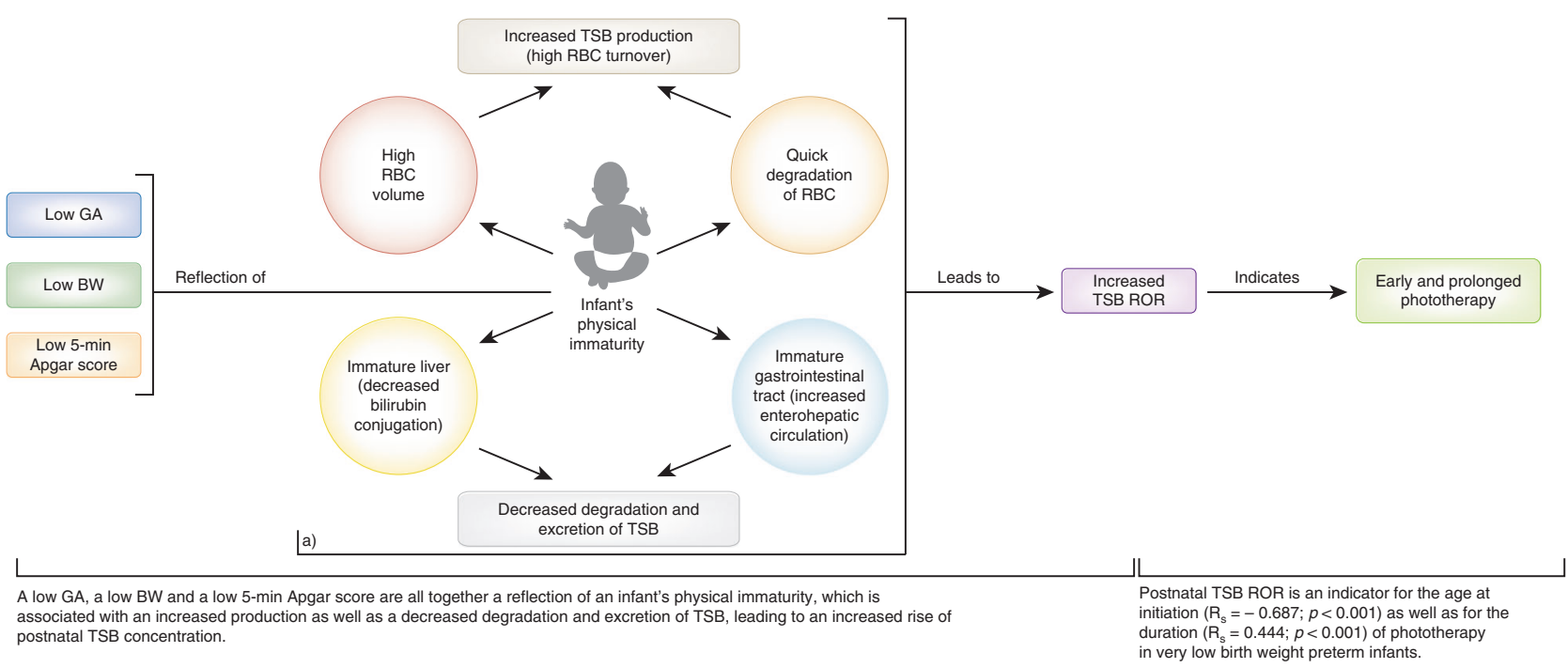

'Department of Neonatology, Charité - Universitätsmedizin Berlin, Berlin, Germany Correspondence: Monika Berns (monika.berns@charite.de)

Received: 28 October 2019 Accepted: 28 October 2019

Published online: 11 November 2019 